\title{
In-house R\&D, outsourcing or alliances? Some strategic and economic considerations
}

Citation for published version (APA):

Narula, R. (1999). In-house R\&D, outsourcing or alliances? Some strategic and economic considerations. MERIT, Maastricht Economic Research Institute on Innovation and Technology. MERIT Research Memoranda No. 007 https://doi.org/10.26481/umamer.1999007

Document status and date:

Published: 01/01/1999

DOI:

10.26481/umamer.1999007

Document Version:

Publisher's PDF, also known as Version of record

\section{Please check the document version of this publication:}

- A submitted manuscript is the version of the article upon submission and before peer-review. There can be important differences between the submitted version and the official published version of record.

People interested in the research are advised to contact the author for the final version of the publication, or visit the DOI to the publisher's website.

- The final author version and the galley proof are versions of the publication after peer review.

- The final published version features the final layout of the paper including the volume, issue and page numbers.

Link to publication

\footnotetext{
General rights rights.

- You may freely distribute the URL identifying the publication in the public portal. please follow below link for the End User Agreement:

www.umlib.nl/taverne-license

Take down policy

If you believe that this document breaches copyright please contact us at:

repository@maastrichtuniversity.nl

providing details and we will investigate your claim.
}

Copyright and moral rights for the publications made accessible in the public portal are retained by the authors and/or other copyright owners and it is a condition of accessing publications that users recognise and abide by the legal requirements associated with these

- Users may download and print one copy of any publication from the public portal for the purpose of private study or research.

- You may not further distribute the material or use it for any profit-making activity or commercial gain

If the publication is distributed under the terms of Article $25 \mathrm{fa}$ of the Dutch Copyright Act, indicated by the "Taverne" license above, 


\title{
In-house R\&D, outsourcing or alliances? Some strategic and economic considerations
}

\author{
First draft, 27 January 1999
}

\section{Rajneesh Narula}

Senior Research Fellow

University of Oslo, and MERIT, Maastricht

home page: http://www.bigfoot.com/ r.narula

\author{
Corresponding address: \\ Dr R. Narula \\ ESST \\ University of Oslo \\ PO Box 1108 Blindern \\ N-0317 Oslo, Norway \\ Phone: +47 22858962 \\ Fax: +47 22858984 \\ e-mail: R.Narula@bigfoot.com
}




\title{
In-house R\&D, outsourcing or alliances? Some strategic and economic considerations
}

\author{
Rajneesh Narula \\ University of Oslo, the STEP Group and MERIT
}

\begin{abstract}
Our primary objective here is to suggest when, and under what circumstances is it advantageous for firms to engage in the use of either in-house $R \& D$ activity, $R \& D$ outsourcing or R\&D alliances. The extent to which a firm will use either of these modes is very much dependent on the technology and the nature of its competences: different technologies are at different stages of evolution within any given technological paradigm. Technologies also have different levels of uncertainty and rates of technical change. The decision to collaborate or internalise is also dependent, inter alia, on the nature of the technology relative to the firm's core competences, and the distance of the firm's technological activities from the market. Secondarily, we discuss some considerations in the choice of partners, due to strategic issues as well as the peculiarities of the innovation process.
\end{abstract}

\section{Introduction}

It is widely accepted, and apparent, even to the most casual observer of business news, that cooperative agreements are being signed continuously, and in ever greater numbers with every passing year. This is a phenomenon that has sparked the attention of managers, national and supra-national regulators, policy-makers and academics alike. It is argued by some that this phenomenon is the death knell of the traditional firm, that firms will become increasingly 'virtual'. To paraphrase Samuel Clemens, we believe that the death of the firm is greatly exaggerated. While it is true that there is a growing amount of outsourcing taking place, we feel that there are a great many misconceptions about cooperative agreements, and this has to do with two facts.

First, there is a definitional problem. The fact is that there are a wide variety of such agreements, all of which have fundamental differences in their structure and objectives, but are referred to as strategic alliances, collaborative agreements, or networks or outsourcing. We intend to clarify this issue. Our primary objective here is to suggest when, and under what circumstances is it advantageous for firms to engage in R\&D activity internally or externally, distinguishing between the use of in-house $R \& D$ activity, $R \& D$ outsourcing and $R \& D$ alliances. We shall also discuss some considerations in the choice of partners, due to strategic considerations as well as the peculiarities of the innovation process.

Second, cooperative agreements have different objectives, depending on what aspect of the value-added chain we are dealing with. This paper focuses on the somewhat narrow area of collaborative $R \& D$ activity. We intend to explain what the role of cooperative agreements are in this crucial area of technological competence development is, in light of the growth of what is best described as the multi-technology corporation. We also intend to 
explain how the kind of R\&D collaboration that a firm undertakes (if it should do so at all) depends on the industrial sector of innovation, the rapidity of technical change within the sector, the firm's distance from the technological frontier, the core competences of the firm, its strategic position within an industry, the technological paradigm and the distance of the firm's technological trajectory from the market.

We propose that these trends can be explained by combining a resource-based view of the firm, in addition to traditional economic rationale, and by acknowledging the special nature of innovative activity, which has certain unique characteristics that separates it from production activities, as well as the strategic nature of firm-decision making.

\section{The characteristics of ownership advantages and technology}

Although there are many motives for undertaking R\&D alliances which Hagedoorn (1993) classifies into those relating to general characteristics of technological development; those relating to the innovation process; and those relating to market access and opportunities. One of the primary objectives of $R \& D$ collaborative ventures is to learn, for the basic reason that the ability of firms to compete effectively for market share is a function of their ability to maintain and renew its firm-specific assets. These assets are commonly referred to as ownership advantages. An important distinction needs to be made about the nature of ownership advantages of companies, which, in knowledge-intensive firms, comprise different forms of knowledge. There are two types of knowledge that comprise the ownership advantage of firms. First there is technical knowledge which is made up of what might traditionally be defined as technology, both embodied in plant and equipment (and to a large extent codifiable), as well as the employee-specific knowledge that is only to a limited degree non-tacit. Second, there is organisational knowledge, which comprises knowledge of transactions, both intra-firm and inter-firm. In general, throughout the current paper, we focus on R\&D alliances whose primary purpose is to acquire technical knowledge and to generate innovations. We define innovation to be product or process developments that affect the output per unit cost (Narula 1993). Although, as per our definition of innovation, improvements in output per unit cost can (and frequently do) occur through the acquisition of organisational improvements, and/or the ability to undertake inter-firm transactions more efficiently, we limit ourselves in this paper to study only alliances to undertake overt $R \& D^{1}$.

$$
\text { ****FIGURE } 1 \text { ABOUT HERE***** }
$$

\footnotetext{
${ }^{1}$ For a discussion of organisational knowledge, see Inkpen $(1996,1998)$
} 
There are different ways of classifying innovatory activities. In this paper we view innovation along a continuum between basic research to development, with the determining factors being (a) the generic nature of the innovation and (b) the distance from market. By generic nature, we refer to a distinction introduced originally by Kuznets (1962) and used in a modified way by Arora and Gambardella (1994) and Trajtenberg et al (1997). Figure 1 summarises our basic argument. Knowledge that is 'basic, or 'generic' represents knowledge that is not country or demand-specific, and is less appropriable than 'applied' or 'specific' ('applied D' in Figure 1). It is important to highlight that we are speaking of research outcomes, since laboratories are engaged in several projects simultaneously, and since technological development is an uncertain process, it is not always possible to say ex ante whether a certain project is 'basic R' or not. Nonetheless, a distinction can be made between the extremes. On the one hand, firms can explicitly engage in projects that are more 'blue sky', or pursue scientific research that has no clear market value in the short run, aim to change the technological paradigm, or have a major impact in defining general laws rather than solving particular problems. On the other hand, demand-specific modifications or adaptations can be explicitly undertaken, which are more context-specific and are clearly 'applied D'. It is worth noting that regardless of the basicness or generic nature of the knowledge, there is always some extent of context specificness. Even codifiable technology is context-specific to at least some extent (Cantwell 1991). Because technology is the cumulative sum of innovations and proceeds incrementally based on "localised search" patterns centred on the technology possessed by the firm in previous periods, the technology of any given firm is unique, such that no two firms can have exactly the same kind of technology.

\section{The characteristics of cooperative agreements in innovative activities}

Some distinction needs to be made of the difference between the following three terms which are often mistakenly used as synonyms: collaborative or cooperative agreements, networks and strategic alliances. Cooperative agreements include all inter-firm cooperative activity, while strategic alliances and networks represent two different (though related) subsets of inter-firm cooperation.

Inter-firm cooperative agreements are intended to affect the long-term product-market positioning of at least one partner (Hagedoorn 1993). In this paper we are specifically interested in strategic technology alliances or R\&D alliances where innovative activity is at least part of the agreement. What differentiates an R\&D alliance from a network or outsourcing agreement are the underlying motives of the cooperation (Figure 2). Networks (or 
R\&D outsourcing agreements) have a primarily cost-minimising objective, and are typically customer-supplier relationships. Note that by 'costs' we mean to include $\underline{\text { both }}$ transaction and production costs. R\&D alliances represent agreements which are quasi-hierarchical in nature that have both a value-enhancing and strategic motive in addition to a cost-minimising one (Narula and Hagedoorn 1999). This differentiation has its roots in an ongoing debate within the management literature of the relative merits of various underlying theories explaining the behaviour of firms to use markets and hierarchies (see Madhok 1997 for a more in-depth analysis of the various aspects of this debate). On the one hand, there is the transaction costs/internalisation perspective, which derives its roots in the work of Williamson (e.g., 1975) and Coase (1937) which explains the behaviour and organisational mode and the mode of entry of firms based on their need to minimise net transaction costs faced by the firm. This body of literature has been expanded by others including Buckley and Casson (e.g., 1976), Hennart (e.g., 1988, 1993) and Rugman (e.g., 1980). On the other hand, there are the organisational capability and technology based views of the firm developed in parallel by several schools, including Penrose (1959), behavioural theory (Cyert and March 1963) and the economics of technological change (Nelson and Winter 1982). More recent work includes that of Kogut and Zander (1993) and Hill, Hwang and Kim (1990), and Cantwell (1991) among others who have highlighted the fact that firms undertake decisions based on the need to enhance their technological and organisational capabilities because they need to enhance the value of the firm. Madhok's (1997) perspective that the two schools may be regarded as complementary to each other underlies our understanding of strategic technology partnering.

****FIGURE 2 ABOUT HERE*****

R\&D alliances are of a special nature: this is the one aspect of value adding activity that continues to be highly centralised and internalised, even in a domestic scenario. In general, while production activities have gradually been increasingly internationalised, there has been relatively little internationalisation of R\&D (see e.g., Patel and Pavitt 1997, Dunning and Narula 1995, Archibugi and Michie 1995). Nonetheless, it is worth noting that there has been some growth in the technological development activities of MNEs relative to its level 20 years ago, and these changes indicate two trends worthy of note. First, in addition to overseas R\&D activities associated with demand side factors, there has been a growing extent of foreign R\&D activities by firms in response to supply-side factors (Florida 1997). Second, there has been a growing use of external or quasi-external technological sources. Although there is little systematic and thorough analysis of this process, companies such as Philips and 
Akzo-Nobel are currently attempting to externally source $20 \%$ of their technology needs (van Hoesel and Narula 1999). However, two important points needs to be noted here. First, external technology sourcing can either be undertaken through outsourcing or through $R \& D$ alliances. Second, external technology acquisition is NOT normally a substitute for in-house R\&D activities. Veugelers (1997) demonstrates that there is a positive relationship between external technology sourcing and internal $\mathrm{R} \& \mathrm{D}$. This has to do with the complexities of the multi-technology firm, which is dealt with in greater detail in a later section.

The special characteristics of $R \& D$ activities require certain important caveats to be noted. First, there is a fundamental difference in the definition of $R \& D$ alliances and nonR\&D strategic alliances. Traditionally alliances have been defined as agreements which have a long-term and formal aspect which link aspects of their businesses (Porter and Fuller 1986). Strategic technology partnering, as used here, refer to agreements that are intended to undertake specific tasks and are generally terminated at the completion of these tasks, and are by definition short- (and often fixed-) term in nature, although relationships between particular partners may in fact endure because of series of interlocking projects and overlapping consortia (Hagedoorn 1995, Duysters and Hagedoorn 1995). The evidence on partnering in R\&D alliances would suggest that inter alia, one of the primary reasons to partner is in order to build trust, as well as to discover what partners and potential partners may have to share. While trust is also important in outsourcing, it is less crucial, since the interdependency of the two organisations is minimal. These issues are raised again in a later section.

Second, it is important to note that there is a strong causality between size and the propensity to engage in $R \& D$ cooperation, given the need to have sufficient resources to undertake R\&D (Hagedoorn and Schakenraad 1994). Third, trade barriers do not play a major role in inhibiting the relocation of $R \& D$, except where such $R \& D$ is associated with production (i.e. adaptive R\&D). Stand-alone R\&D facilities, which are common in knowledge-intensive sectors, are often located in response to supply-related considerations. Such activities have not necessarily been affected by the decline in transaction costs due to globalisation - skilled human capital and knowledge (in either tacit of non-tacit form), has long enjoyed relatively restriction-free freedom of movement across borders. Although certain improvements such as the common patenting system, and the harmonisation of regulations may have lowered costs in general, the benefits of lowered communication costs (due inter alia to ICTs) have occurred on a global level. 
The characteristics of the innovation process are well-documented. We should like to highlight the firm-specific nature of the output of R\&D activity, and the influence it has on the mode of governance utilised. Some research has been conducted on the propensity to undertake different types of agreements in R\&D (see Hagedoorn and Narula 1996, Mowery et al 1998, Croisier 1998, Narula and Hagedoorn 1999) that indicates the preference of certain modes of R\&D alliances in particular industries. For instance, mature sectors tend to utilise more equity-based agreements than fast-moving and high-tech sectors, and that these differences exist across industries but not across countries. However, these studies rarely address the choice of fully internalised $R \& D$ (in-house $R \& D$ ) compared to quasi-internalised (alliances) and externalised activity (R\&D outsourcing). The important thing that we should like to emphasise is that while it is true that firms engaged in asset-exploiting activities such as production or sales have a broader choice of options that include wholly owned subsidiaries and arms-length technology acquisition, some of these options are simply not available to firms that are seeking to undertake R\&D. First, because technology is tacit by nature, and as far as technology development is concerned, even more so. Arms-length transactions are simply not as effective, particularly in technology-intensive sectors or new, 'emerging' sectors, even if markets for these technologies were to exist. The further away these technologies are from the market (i.e., more research oriented than developmentoriented) the less likely that technology can be obtained through market mechanisms. Besides, its partly-public good nature prevents prospective selling firms from making technologies available for evaluation, and without doing so, the prospective buyer is unable to determine its worth. Markets therefore, are liable to fail in their ability to function. In other words, completely externalised markets for knowledge may be difficult to create and sustain under certain circumstances, paving the way for firms to acquire knowledge through quasiexternalisation (through alliances or networks), or through internalisation (by in-house R\&D). On the other hand, as Madhok (1997) notes, the failure of hierarchies to function may be the reason to undertake alliances, rather than because of market failure. In the case of a multitechnology firm, which has several divisions, and division A requires technologies that may be available from Division B, there are nevertheless costs of implementing and adapting the knowledge. This cost may be prohibitive, such that a firm may consider collaboration rather than internally transferring the knowledge from another division of the same firm. This is, admittedly, an extreme scenario. But even where the technology required by one subsidiary was available to another subsidiary in another location (even within the same product division and in the same country), the context-specific nature of knowledge may mean it is still easier 
to collaborate with an external firm rather than transfer from an internal source. This also represents a powerful argument for the centralisation of $R \& D$ activity. Furthermore, the decision to partner rather than internally transfer may be mediated by the desire to partner to seek state-of-the-art, which may not reside in the subsidiary.

\section{The characteristics of innovation within sectors and technological paradigms}

In this section, we will discuss the evolution of technologies, and how this affects the innovation process. The maturity of the technology, and its characteristics, determines the extent to which the innovation process can be internalised (between in-house $R \& D, R \& D$ outsourcing and R\&D alliances). Obviously, every technological trajectory of each individual firm is unique, since the innovation process is path-dependent. Nonetheless, since innovation (in the sense that a product or process is new) is also dependent on the last-best (i.e., state-ofthe-art) innovation. If firm $\mathrm{A}$ is engaged in developing an innovation in a given technological paradigm, it must strive to improve (or at least take into account) NOT its own last-best innovation, but the last-best innovation that has been patented, or is otherwise available on the technological market, even if this was created by firm B. Thus its path-dependency is always tempered by the state-of-the-art, and this means that roughly speaking technological trajectories of different firms within any given technological paradigm are similar. At the risk of over-simplifying, technologies (within a given paradigm) evolve through different stages, and these can be viewed as being determined by two factors: the level of uncertainty in the nature of the technology and the speed of technical change within it. Figure 3 places these two dimensions into context, using a $2 \times 2$ matrix. The arrows indicate the most common trend of evolution of a technology, from quadrant A to D.

\section{****FIGURE 3 ABOUT HERE*****}

The concept of uncertainty within the innovation process is well-understood, and we shall not delve into it further. In general, the newer the sector, and the closer it is to 'basic R', the higher the level of uncertainty. As the technology becomes diffused and codified, the level of uncertainty drops.

The rate of technical change is determined not just by the level of uncertainty of technological change, but the number of possible directions in which it can develop, because there are multiple alternatives to an innovation. Thus, while technological change may not always be perceptible or discrete, but it is continuous. It is not however determined by one company or idea but numerous path-dependent solutions being developed independently by 
several innovators or would-be innovators. In other words, while the innovation being developed by one company is unique to it, it represents one of many possible solutions to a technological hurdle. What determines whether technical change is rapid or slow? In some cases it is easy to determine this. To take the example of the further miniaturisation of integrated circuits. In this case there is little uncertainty about the outcome of the four technological solutions being proposed: the objective is to squeeze even more active devices onto a small wafer. Within the existing technological paradigm, the solution is to use lower wavelengths in the etching process. The current technology relies on lens-based tools which use deep ultra-violet light, which are limited by the minimum wavelength that can be used, since traditional optics become opaque below certain wavelengths. There are at least four different technological trajectories being proposed, and being pursued by various consortia. IBM and Canon plan to replace this with X-rays, while Siemens is working on ion-beams. Intel, Motorola and AMD are working with soft-X-rays ${ }^{2}$. It only remains to be seen which of these technological trajectories will be dominant. Markets for this innovation already exist, and these markets operate efficiently. The nature of the property rights of the innovation are also clear. Such a technology could be classified in quadrant $\mathrm{C}$ in Figure 1. However, there are limitations associated with making chips smaller with the current materials, and this requires a complete change of technological paradigm to other materials such as plastics and gels from copper and silicon dioxide but this is an unknown- and still theoretical- area. Such technologies would be considered to be in quadrant A or B. The case of most steel technology is clear - we are dealing with a slowly-evolving and mature technology which demonstrates minor but consistent innovations over time. The technology is to a great extent codifiable, widely disseminated, and the property rights are well-defined. Thus it is located in Quadrant D. However, the speed of technical change is not always clear, but this depends on the definition of the technology, which depends on the question of technological paradigm, and practicality of research outcomes. Take the case of battery technology. Although there has undoubtedly been vast improvements in the technology, the basic paradigm has not changed dramatically in the 200 years since Volta. Although numerous alternatives have been proposed to store energy, none of these technologies has replaced the chemical cell in any commercially viable application. We are nonetheless, continually assured that a technically and economically practical electric car is just around the corner, due to some recent breakthrough in battery technology. Is technology evolving rapidly or slowly in this industry? There are convincing arguments to locate this industry in either quadrant D, A or B. Perhaps

\footnotetext{
${ }^{2}$ Webb, Jeremy 'Crashing the Barriers', New Scientist, 7 November 1998, pp 42--47
} 
the way to see this is that there is more than one technological paradigm. There is slow technical change taking places within the old technological paradigm - that of chemical batteries - for surely the only major changes over the past century have been in terms of increasing the efficiency of these devices. It would thus be in quadrant D. There are new technological paradigms, but because they are new and commercially unproven, the outcome of the selection process is unknown, so it is impossible to determine ex ante whether the research outcome is in quadrant A or B. Equally importantly, even where a technological paradigm is established, within this, there would be several innovating firms, each following its own innovation trajectory. Which of these trajectories will be the commercially successful one is also unknown. So unless a trajectory becomes 'established' as a dominant one, within a given technological paradigm, it is also uncertain whether technical change is rapid or slow. What we are trying to suggest here is that technical change and innovation cannot be viewed from an entirely scientific perspective, but also from its viability from a commercial point of view.

Another important point to be noted is that in both quadrant $\mathrm{A}$ and $\mathrm{B}$, we are dealing with 'new' technologies within technological paradigms and new trajectories within technologies. These industries share certain characteristics: neither the dominant technological trajectory is known, nor indeed the objective. The technology is highly tacit, and not necessarily commercial. The property rights are also unclear. No distinction is made between the two quadrants simply because none is possible, except perhaps to suggest that in quadrant B there is a clearly commercially accepted trajectory, within a given paradigm.

\section{in-house or collaborate? The 'when' of R\&D alliances}

Let us summarise the discussion thus far. We have emphasised that cooperative outsourcing is not the same thing as an alliance, and these represent two clearly different options available to firms. So firms are faced with a three way choice for any given R\&D project: inhouse R\&D, outsourcing or alliance. We have highlighted that the importance of cost based issues is crucial to the understanding of cooperative agreements. However, it is important to realise the limitations of cost-based decisions, and the centrality of resource-based decisions in certain instances. We have argued that the kind of cooperative agreements undertaken in R\&D are determined by the nature of innovation, in the sense that separating basic research from applied development provides an important dimension to understand the need to collaborate: that of the distance-to-market. This allows us to separate the search for technical knowledge from the search for knowledge to improve transactions. A second and related 
factor is the evolution of technologies within particular technological paradigms, and how the levels of uncertainty and speed of technical change affect the nature of $R \& D$ and the research outcome. In the next section, using the dimensions developed here, we will deal with trying to interconnect these issues - under what circumstances should firms consider R\&D alliances, in house R\&D or out-sourcing?

\section{Cost-based explanations and their limitations}

Before proceeding with the discussion of strategic issues, the efficacy of transaction cost explanations should be further highlighted. The first question that arises, is why have cooperative agreements become so popular so suddenly, since they have existed for as long as markets have? And if we are making a distinction between alliances and networks, why have they increased in popularity at more or less the same time? There can be little doubt that the increase in popularity of cooperative agreements can in part be attributed to reduction in transaction and production costs. First, there has been a substantial decline in the production costs of clearly defined inputs to the value-adding process, as well as the transaction costs associated with their acquisition. By 'clearly-defined' we refer to codifiable, non-tacit inputs to the production process, that have changed the costs of internalisation relative to market and quasi-hierarchical options. In other words, there has been a redefinition of the boundaries of the firm (in the Coasian sense) such that it is increasingly cheaper to undertake such activities outside the firm. The decline in the costs associated with external sourcing have to do with several factors including the decline of costs associated with monitoring agreements, as well as the concurrent decline in the profit margins due to increased cross-border competition and barriers to entry (Buckley and Casson 1998). The ability of firms to monitor the quality of external suppliers due to improved communications, as well as the convergence of technological standards in 'generic' production technologies creates alternatives to direct control, since quality requirements are similar, and if these inputs do not meet specifications the shortcomings can be quickly identified and addressed without costly time delays. One of the largest apparel retailers in the US, whose stock is entirely supplied by a completely independent supplier in India, recently discovered exceptionally high shrinkage rates in its 1999 spring collection. Samples of apparel are normally shipped by courier to the New York headquarters weekly for tests. In addition, video- and teleconferencing on a weekly basis keep the purchasing and quality-control departments of the Indian company and the US company allow quick responses to be made to potential crises, and a potential disaster was averted. Two 
decades ago, the error would only have been discovered after the shipment had arrived in the US, possibly even bankrupting the company.

The cost of policing agreements and the risks of shirking have also declined. Violations in contracts, when discovered, and are not resolved to the mutual satisfaction of all parties, have mechanisms for redress, as legal frameworks and systems on an international scale have become similar, and arbitration opportunities are available through quasi-legal (through trade and industry associations) and legal (e.g., amongst the countries of the European Economic Area) means. Increased competition on a global basis, as well as increased reliance on international orders by hitherto domestically oriented firms means that even where, say, a parts supplier in Vietnam fails to meet its obligations, and no legal mechanisms for redress exist for the German customer, the loss of reputation within the industry and possibility of losing a major customer limit the possibility of default.

These costs, it should be noted, have declined to a greater extent for arms-length and quasi-hierarchical arrangements more than for internalised arrangements. A majority owned subsidiary (whether acquired or greenfield) must be coordinated organisationally with the rest of the company, and considerable cultural differences continue to exist between locations even where legal and social conditions have been harmonised, such as the EU. The problems of organisational coordination are still significant, especially where (as is increasingly popular) international expansion is undertaken through M\&A. Thus, the benefits of full internalisation may not be great enough relative to the falling costs of quasi-hierarchies or markets.

Indeed, declining transaction costs associated with contractual or quasi-internalised relationships in addition to falling profits margins (due to increased competition) has led to a dis-integration of certain firms in particular industries, as they seek flexibility and lower risk, which have hitherto preferred vertical integration. Some notice has been made of the process of dis-investment, that, coincidentally or not, appears to have become quite commonplace during the last decade (Benito 1997). This has occurred to only a limited extent in the case of $\mathrm{R} \& \mathrm{D}$, and only inasfar as $\mathrm{R} \& \mathrm{D}$ outsourcing is concerned.

More importantly, not all decisions are made simply according to cost considerations. We earlier made a distinction that globalisation has led to a decline of outsourcing of 'welldefined' inputs. Not all inputs are outsourced, despite the fact that they may be more cheaply available from external sources. Despite the existence of the virtual firm where almost all activities are sub-contracted, this can only be undertaken where the product and most of its components are well-defined and generic. That is to say, the technology behind the product is 
codifiable and standardised and for which multiple non-distinguishable sources of these inputs are available. The same argument holds true for $R \& D$ activity. In other words, $R \& D$ outsourcing is only undertaken where doing so does not threaten the competitive advantages of the company. It is important to realise that $R \& D$ outsourcing is essentially a customersupplier relationship, rather than an interaction between two partners as in an alliance.

Where either the know-how for the inputs is unique and non-substitutable (either because it is proprietary and firm-specific, or it is location-specific), or it is tacit and noncodifiable, cost based issues become less relevant, and strategic (and resource) considerations, (such as core competences) take on greater importance. We examine these issues separately.

When the input necessary is unique. If the input is firm-specific (for instance, the Mac operating system), the cost becomes less relevant ${ }^{3}$. In such cases, the resource availability becomes important. When Apple withdrew its clone licenses, the Mac clone companies had to stop manufacturing. In these cases, the relationship between the firm and the suppliers is much more strategic, since the alliance determines the long term product-market positioning of at least one of the firms. Where the resource is not completely internalised by the firm, but is particular to a location or a region, a similar scenario applies, only that this affects production costs more than transaction costs. There is a well-developed literature on the role of national (and regional) systems of innovation and their influence on the location of companies (see e.g., Edquist 1997, Lundvall 1992). This may be either be to benefit from socio-technological inputs such as educational establishments, infrastructure, or simply to exploit economies of agglomeration, and to seek possible spillovers. Where such inputs are unique, that is, the resource is unavailable elsewhere, and proximity to its source is necessary, the choice of location is production-cost-independent (Sachwald 1998). It is to be noted that although the cost issue may be secondary in the case of an immobile location-specific factors, it does not mean that it is unimportant ${ }^{4}$. Since these resources are crucial to the survival of the firm, they take on a strategic importance that clearly outweighs any cost-savings that might derive from outsourcing.

Tacit or non-codifiable inputs. Because of their nature, certain inputs to the value adding process are less clearly defined. This is especially the case with most innovatory

\footnotetext{
${ }^{3}$ Although there exists a (albeit rough) substitute (Windows). For a firm that wishes to enter the Mac market, however, there is no choice. Nonetheless, above a certain cost, the cost will become relevant, since an alternative does exist.

${ }^{4}$ It may also be the case that proximity in necessary in the case of a customer-supplier agreement due to just-intime manufacturing. Where cooperative agreements are undertaken in such a case, such decisions are mainly cost-based. However, such types of agreements are out of the scope of the current paper, since the primary
} 
activities, but is also true for specialised resources where innovation is not involved, but the final product is tacit in nature. Therefore, it is much more difficult to outsource these aspects of the production process, because it is hard to specify the quality of the resource. Identifying a supplier who would be able to produce it may be difficult, since its nature is difficult to specify ${ }^{5}$. Where the product has a high level of tacitness, property rights will most likely be unclear. In other words, the market for such resources are hard to establish. Where such supplier firms do exist and property rights are well-defined, they are able to charge monopoly rates, since they have access to unique resources, and price comparisons are thus impossible. In addition though, closer cooperation than might be provided by networks is also necessary, because (i) the contracting firm is itself unsure of the nature of the resources, and must monitor the activities of the supplier firm more closely. As Cantwell and Santangelo (1999) discuss, greater tacit and uncodified knowledge require closer, face-to-face interaction (ii) the customer would like to avoid the potential loss of his assets to the supplier company (this is examined in greater detail in the next section). In such cases, outsourcing is the least preferred option.

In discussing these lacunae to the cost-based decision-making of the firm, it seems clear that strategic and resource-based decisions may outweigh the need to acquire cheap inputs. In fact, the choice between the three modes of undertaking R\&D activity must lie also with internal factors and technology-specific factors. In the next section we analyse how these factors determine the choice of modality, and the kind of partner.

\section{The multi-technology firm and substitutability between external vs. internal technology development}

The previous section leads us to the observation that where firms are faced with the erosion or stagnation of their core competences, and the subsequent decline in the competitiveness, they are less likely to take a cost-based approach.

One of the primary reasons for the growth of alliances noted by almost all major studies of alliance motivations (see e.g., Hagedoorn 1993, Glaister and Buckley (1996) and Osborn and Hagedoorn (1997) for a review) has been the need to seek complementary technologies. The growing cross-fertilisation of technologies is by now axiomatic. As BMW

learning objective is simply to achieve organisational learning, that is, to acquire knowledge regarding the location rather than a product.

${ }^{5}$ Cowan and Foray (1997) argue that while codification is never complete, the extent to which knowledge is codified depends on the costs and benefits of doing so. Although new technologies have lowered the costs of 
is fond of proclaiming in its print advertisements (circa 1998), its cars have more electronics and computing power aboard than the Apollo 13 mission: A car is no longer simply a mechanical engineering product, but requires technological competence in areas as diverse as ceramics, computing, communications, plastics, among others. By taking the (simplistic) view that alliances allow firm A to utilise some of firm B's competences, it is sometimes assumed that firm $\mathrm{A}$ is making a cost-economising choice allowing them to specialise or focus on their core competences. In fact, as Granstand et al point out, this is not the case. Most multitechnology firms maintain multiple or 'distributed' competences, by maintaining a high level of in-house expertise in several fields. order to monitor externally developed knowledge and integrate it with its other production inputs. In other words, despite the growth in cooperative agreements, this does not necessarily translate into a decline in the need for firms to engage in in-house R\&D (Mowery et al 1998, Cohen and Levinthal 1990). However, the decision whether to internalise or collaborate (and within collaboration, to have an alliance or outsource), must be seen, within a particular technology, as dependent on several issues, including (a) the nature of the core competences of the firm, and the centrality of the particular technology to its competitiveness, (b) within any given technology and set of core competences, on the distance-to-market, and (c) within any given technology, and for any particular learning objective, on the structure of the industry and 'game-theoretic' determinants. We discuss each of these briefly.

\section{Core competence considerations and the possibility of collaboration}

There remains another question that is associated with the type of innovation. As Granstand et al explain, firms that have multi-technology competences have a graduallychanging competences, as new technologies become more important while others become obsolete, albeit gradually. Thus they classify technological competences into four types: niche competences, distinctive competences, background competences and marginal competences. Partnering will depend to some extent on the centrality of the area of cooperation to the firm's specialisation. A second factor that decides the nature of collaboration is the type of innovation from the point of view of it being systemic or autonomous (Granstand et al 1996). This corresponds with Quadrant C and B respectively. We add a third classification to this: where the type of innovation is unknown. This is the case with the most 'basic R', where the research outcome is scientific rather than technical, and may change the technological paradigm. However, just as the ramifications of the invention of the bipolar transistor in 1947 
(seen at the time as not much more than a novelty) were not apparent till several years later, the knock-on effects are as-yet undetermined. Within the framework of Figure 3, this would be quadrant $\mathrm{A}$.

When the innovation is autonomous or unknown, in the sense that it is not directly (or not expected to be) related to the main areas of its current innovatory competences (i.e., niche or distinctive), and it can be pursued independently from other innovations, it will more likely undertake this through external means. This is very much the case when large pharmaceutical firms have undertaken alliances with small (but innovative) biotechnology firms. Where the expected benefit of the new area of research is unknown or marginal, the firm will not be interested in investing large internal resources, until the benefits are more tangible, and as such a risk-reduction strategy through collaboration is interesting. However outsourcing is impossible, since the nature of the output is unknown. In the case of biotech start-ups and large pharmaceutical firms this was resolved by the large firms acquiring a minority stake in the small firms. This gave the large firms an 'option' to acquire (and thus internalise) or otherwise control the research output of the small firm were the technology to develop a practical value to them. If the research outcome proves to be not commercially viable or not the prevailing technological paradigm, the relatively low costs of this strategy are not a matter of great concern. Where the area of research and the kind of innovation sought is systemic, in the sense that the innovation may dramatically affect its niche or distinctive competences, and/or requires input from several other areas of research that the firm currently undertakes, the situation is more complicated. The firm would prefer to internalise the technology, given its in-house capacity. If the technology were externally owned, it would be prefer to acquire, and only where that were not possible, to consider a $R \& D$ alliance. In addition, property rights protection is as yet undetermined - for instance, the question of cloning and gene manipulation research output is still an area of some controversy (quadrant A/B). Property right protection is thus achieved through secrecy, and collaborative research therefore is a risky option.

Where property rights are clearly defined, technical change is slow and uncertainty is low, (quadrant D), R\&D cooperation is more easily undertaken, particularly traditional modes (involving equity) and technological outsourcing and networking.

In fast-evolving sectors such as quadrant $\mathrm{C}$, where nominally property rights protection exists, patenting is often a limited source of competitive advantage given the rapidity of change. Firms do not always have recourse to patenting as a means to protect new 
and rapidly evolving technologies, and must rely on secrecy, or on lead-time ${ }^{6}$, or by coinventing with a potential competitors (Levin et al 1987). As noted in a survey of European firms, the propensity to patent new products averaged $35.9 \%$ across sectors, and $24.8 \%$ in process innovations (Arundel and Kabla 1998).

Co-invention is a very important means not only to protect property rights, but also to in order to co-opt the competition (Narula and Dunning 1998). Take the situation where two firms in the same industry are pursuing an important new breakthrough independently. Neither can be certain that they will win the race to innovate. As such, it may be in their best interest to collaborate, thus ensuring both that they are jointly 'first': half a pie may be considered better in conditions of uncertainty while there is a probability that there may be none at all (Narula 1998).

\section{Distance to market considerations as a determinant of collaboration}

Creating compatible standards Referring to figure 2, we have made a distinction between 'front-end cooperation', closer to 'applied D', and 'back-end cooperation', which is closer to the 'basic R'. In the case of front-end cooperation, the objective is to actualise the innovation since the distance-to-market is small. This is an important area for alliance activity, where the innovation is fine-tuned to maximise its market potential. One way to do so is to collaborate with competitors to modify similar technologies so as to create de facto industry standards. The selection of partners and the breadth of the partnership tends to be limited, often in response to alternate attempts to create industry standards. Sony, Philips and Sun Microsystems have recently established an alliance to develop software for Home Audio Visual Interoperability (HAVi) architecture so as to allow dissimilar consumer electronics devices to be linked together. This is in response to a similar attempt by Microsoft and Intel to develop Home Application Program Interface ${ }^{7}$. In such alliances, the joint R\&D activity is demand-driven, with a view to expanding the market share of the collaborators on the long run. Their success or failure is partly a function of the number of alliance partners that can be drafted into the agreement, and their market power - the success of the UNIX alliance, and its establishment as a de facto industry standard, as well as the growing popularity of Java are associated with this. Such alliances also face considerable regulatory scrutiny from anti-trust

\footnotetext{
${ }^{6}$ Where the innovator attempts to get the product to market before competitors, with enough lead time, such that by the time they imitate, the first innovator has progressed to a newer and better product.

${ }^{7}$ New York Times, Jan 19, 1999 'Philips and Sony Set a Venture With Sun Microsystems'
} 
regulators. Back-end cooperation, on the other hand, tends to be pre-competitive in nature, and is often sanctioned by regulatory authorities.

How does this relate to the question of core-competence considerations and the evolution of technological sectors? It seems clear that technologies that are new (such as in quadrants $\mathrm{A}$ and $\mathrm{B}$ in Figure 3) are unlikely to attract much front-end cooperation. Nonetheless, even though most of the activity might be 'basic R' there is some variation, with certain alliances being focused in activities closer to the market than others. As Figure 4 tries to illustrate, as technologies evolve, there is increasing emphasis on front-end cooperation, with the widest range of collaborative opportunities being attempted in Quadrant C.

\section{****FIGURE 4 ABOUT HERE*****}

\section{Game-theoretic reasons to collaborate}

Learning to trust As Kay (1997) explains, 'it is necessary to engage in networks with certain firms not because they trust their partners, but in order to trust their partners' (Kay 1997: 215). This strategy is much more important than is given credit for. When companies decide to seek cost-savings by sharing a blue-sky innovatory process, or any other high cost/high risk project, its makes sense to do so with a partner with whom no free rider dangers exist. In other words, although it is impossible to be certain about the outcome of an alliance, there is a higher probability that where trust has been created in a previous alliance, the alliance is more likely to be successful.

'if they do it, it must be a good thing' In addition, there is the follow-my-leader strategy, as originally highlighted by Knickerbocker (1973). Firms seek partnerships in response to similar moves made by other firms in the same industry, not always because there are sound economic rationale in doing so, but in imitation of their competitors.

Partnering with unknown partners Why would a potential partner wish to collaborate with another which has limited or as-yet-undemonstrated resources to offer? First, because of the nature of innovation, the only way to determine the nature of a potential partner's research efforts is to examine them. One way it can do so is by engaging in some form of mutual hostage exchange, which an alliance provides. Second, even where the partner's resources prove to be of a limited or inappropriate nature, and the alliance is terminated prematurely, information about its former partner's competencies are then available to either firm in future periods, should it require competencies similar to those on offer by its ex-partner. Third, as Hagedoorn and Duysters (1997) have argued, while selecting partners that are well- 
established players in existing technologies may represent profit maximising situation, it is optimal only in a static environment. In a dynamic environment, where there is a possibility of technological change (or even a change in technological trajectories), having ties to a wide group of companies, including companies that have yet to demonstrate their value, represents a higher learning potential.

Have more alliances than necessary. The high rate of failure of alliances and their inherent instability (Inkpen and Beamish 1997) means that it is a good idea to have redundant agreements - not all agreements will be successful for all parties concerned, and in addition to allowing firms to discover what cards their competitors have up their sleeves, it permits them to 'learn about learning' and the art of managing alliances.

\section{Conclusions}

This paper makes several points. First, that alliances are not a replacement for in-house R\&D - the external acquisition of technology may have increased considerably over the last two decades, but in most cases, the external acquisition of technology requires considerable inhouse $R \& D$ expenditures in order to utilise these acquired technologies, since all knowledge, no matter how codifiable, is context-specific to some extent. Unlike other forms of valueadded activity, $R \& D$ is less amenable to externalisation, given its partly-public good nature. The role of knowledge as a source of competitive advantage is an ever-growing one, and the acquisition of knowledge (be it organisational or technical) is central to the survival of the firm. Despite the fact that firms have sought rationalisation and the boundaries of the firm have shrunk in response to declining costs of externalisation, $R \& D$ has not experienced the same forces. As Granstand et al (1996) have pointed out, wherever firms have decreased product diversification, they have increased technology diversification. The growth of external R\&D has gone hand-in-hand with tehgrowth of in-house expenditures.

Second, we have emphasised that cooperative outsourcing is not the same thing as an alliance. It is true that there has been a growth in cooperative outsourcing as a substitute for internalisation, but, as Narula and Hagedoorn (1999) explain, there is a fundamental difference between the two modes - outsourcing or customer-supplier networks are driven primarily by cost-economising motives, while alliances are driven increasingly by resourcebased or strategic motives. This is particularly so for R\&D activity.

Outsourcing reflects the need to minimise transaction and production costs for clearly defined inputs to the value-adding process. The decline in the costs associated with external sourcing have to do with inter alia the ability of firms to monitor quality of external suppliers, 
and the decline in the cost of policing and the risks of shirking. Customer-supplier networks, or cost-determined agreements can, in a sense, be regarded as quasi-market arrangements. Although cost-based issues do play a role, for alliance activities, this is relatively less important, than for outsourcing.

Second, we have argued that the question of choosing between alliances, outsourcing and in-house $R \& D$ is a function of the kind of innovative activity taking place and the state of the technological paradigm. We argue that there is a gradual evolution of 'new' and 'emerging' technologies towards mature technologies over time, which is reflected in the level of uncertainty and the rate of technical change within the technology for a given technological paradigm.

Third, we have postulated that for any given technology, then, firms have a different propensity to engage in internal R\&D vs. external (or quasi-external) acquisition of technology, and this is also affected within any given level of uncertainty and rate of technical change by the centrality of the technology in question to the core competences of the firm, and the distance-to-market of the innovatory activity that might potentially be undertaken by the collaboration. In addition, other factors such as property rights, and game-theoretic issues (mostly to do with the structure of the industry) also intervene.

We recognise that the framework suggested here is incomplete - we have evaluated the decision of the internalisation of $R \& D$ primarily from a technological perspective. There is little doubt that the decision is much more complicated than we have portrayed: in reality, the decision to partner or not to partner is intermediate by even more variables which determine the question of bargaining power- such as the question of firm size, the number of participants in an industry, the structure of the industry. In addition, it is often not possible to separate the organisational knowledge aspect of learning from the technical one. There are also important dynamic considerations that need to be taken into account with regards the evolution of interfirm collaboration. Innovation and technological development are dynamic and constantly evolving, and agreements are constantly being terminated or upgraded. It has been noted, for instance, that in certain industries alliances are seen as a precursor to M\&A (Hagedoorn and Sadowski 1996). Nonetheless, we believe that the framework presented here clarifies some of the complex issues involved. 


\section{References}

Archibugi, D. and Pianta, M. (1992) The Technological Specialization of Advanced Countries, Dodrecht: Kluwer Academic Publishers

Arora A., Gambardella A. (1994) The changing technology of technological change: general and abstract knowledge and the division of labor, Research Policy,

Arundel, A. and Kabla, I. (1998) What percentage of innovations are patented? Empirical estimates for European firms, Research Policy, Vol 27, pp 127-141

Benito, Gabriel (1997), Divestment of foreign production operations, Applied Economics, Vol. 29, no. 10, pp. 1365-1377

Buckley, P. and Casson, M. (1976) The Future of the Multinational Enterprise, Holmes \& Meier, New York

Buckley, P. and Casson, M. (1998) Models of the multinational enterprise, Journal of International Business Studies, Vol 29, No 1, pp 21-44

Cantwell, J. (1991) The theory of technological competence and its application to international production, in D. McFetridge (ed.) Foreign Investment, Technology and Economic Growth, Calgary: University of Calgary Press

Cantwell, J. and Santangelo, G. (1998) The frontier of international technology networks; sourcing abroad the most highly tacit capabilities.

Cohen, W. and Levinthal, D (1990) Absorptive capacity; a new perspective on learning and innovation, Administrative Science Quarterly, Vol 35, pp 569-596

Cowan, Robin and Dominique Foray, (1997) The Economics of Codification and the Diffusion of Knowledge Industrial and Corporate Change, vol. 6(3), pp.595-622

Croisier, (1998) The governance of external research: empirical test of some transaction-cost related factors, R\&D Management, Vol 28, pp 289-298

Cyert, R. and March, J. (1963) A Behavioural theory of the Firm, Prentice Hall, Englewood Cliffs. 
Dunning, J.H. and Narula, R. (1995) The R\&D Activities of Foreign Firms in the US, International Studies in Management and Organisation, Vol 25, pp39-73

Duysters, G. and J. Hagedoorn (1995) Strategic groups and inter-firm networks in international high-tech industries, Journal of Management Studies, vol. 32, pp. 359381.

Edquist, C. (1997) Systems of Innovation, London: Pinter

Florida, Richard (1997) The globalisation of R\&D: results of a survey of foreign-affiliated R\&D laboratories in the USA, Research Policy, Vol 26, pp 85-103

Glaister, K. and P. Buckley (1996) strategic motives for international alliance formation, Journal of Management Studies Vol 33, pp 301-332

Granstand, O., Patel, P. and Pavitt, K. (1997) Multi-Technology Corporations: Why They Have "Distributed" Rather Than "Distinctive Core" Competencies, California Management Review, Vol 39, pp

Hagedoorn, J. (1993) Understanding the rationale of strategic technology partnering: Interorganizational modes of cooperation and sectoral differences, Strategic Management Journal , Vol 14, pp371-385

Hagedoorn, J. (1996) Trends and patterns in strategic technology partnering since the early seventies, Review of Industrial Organization, Vol 11, pp 601-616

Hagedoorn, J. and Duysters, G. (1997) Satisficing strategies in dynamic inter-firm networksthe efficacy of quasi-redundant contacts, MERIT working paper series 97-016

Hagedoorn, J. and Narula, R. (1996) Choosing modes of governance for strategic technology partnering: international and sectoral differences, Journal of International Business Studies, Vol. 27, pp 265-284

Hagedoorn, J. and Sadowski, B. (1996) Exploring the potential transition from strategic technology partnering to mergers and acquisitions, MERIT working paper series 96010. 
Hagedoorn, J. and Schakenraad, J. (1994) the effect of strategic technology alliances on company performance, Strategic Management Journal, vol.15., pp. 291-311.

Hennart, J. -F. (1988), A Transaction Costs Theory of Equity Joint Ventures, Strategic Management Journal, 9: 361-74

Hennart, J.-F. (1993) Explaining the swollen middle; why most transactions are a mix of market and hierarchy, Organization Science, Vol 4, pp529-547

Hill, C. Hwang, P. and Kim, W. (1990) An eclectic theory of the choice of international entry mode, , Strategic Management Journal , Vol 11, pp117-128

Hoesel, van R and Narula, R. (1998) outward investment from the Netherlands: introduction and overview, in Hoesel, R. amd Narula, R. (eds) Multinationals from the Netherlands, London; Routledge, pp 1-31

Inkpen, A (1998) Learning and knowledge acquisition through international strategic alliances, Academy of Management Executive, Vol 12, pp 69-

Inkpen, A. (1996) Creating knowledge through collaboration, California Management Review, Vol. 39, pp123-140

Inkpen, A. and Beamish, P. (1997) Knowledge, bargaining power, and the instability of international joint ventures, Academy of Management Review, Vol. 22, pp 177-202

Kay, N. (1997) Pattern in Corporate Evolution, Oxford: Oxford University Press.

Knickerbocker, F.T. (1973) Oligopolistic reaction and the multinational enterprise, Cambridge (Mass.), Harvard University Press.

Kogut, B. and Zander, U. (1993) Knowledge of the firm and the evolutionary theory of the multinational enterprise, Journal of International Business Studies, Vol 24, pp625-646

Kuznet, S. (1962) Inventive activity; problems of definition and management, in R. Nelson (ed) The Rate And Direction Of Inventive Activity, Princeton: Princeton University Press 
Levin, R., Klevorick, A., Nelson, R., and S. Winter (1987) Appropriating the Returns from Industrial Research and Development, Brookings Papers on Economics Activity, No 3, pp 783-820

Lundvall, B.(1992) National Systems of Innovation: Towards a Theory of Innovation and Interactive Learning, London, Pinter Publishers

Madhok, A. (1997) Cost, value and foreign market entry mode: the transaction and the firm,

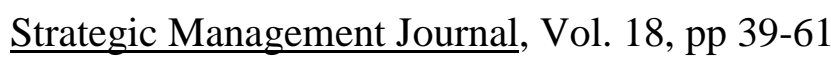

Mowery, D. Oxley, J. and Silverman, B. (1998) Technological overlap and interfirm cooperation: implications for the resource-based view of the firm, Research Policy, Vol 27, pp 507-523

Narula, R. (1993) Technology, International Business and Porter's 'Diamond': Synthesising a Dynamic Competitive Development Model, Management International Review, vol 33, pp 85-107

Narula, R. (1998) Strategic technology alliances by European firms since 1980: questioning integration? STEP Report 1998-04

Narula, R. and Dunning, J. (1998) Explaining International R\&D Alliances and the Role of Governments, International Business Review, Vol. 7, pp 377-397

Narula, R. and Hagedoorn, J. (1999) Innovating through strategic alliances: moving towards international partnerships and contractual agreements, Technovation, forthcoming

Osborn, R. and Hagedoorn, J. (1997) The institutionalization and evolutionary dynamics of inter-organizational alliances and networks, Academy of Management Journal, Vol 40, pp261-278

Patel, P. and Pavitt, K. (1997) The technological competencies of the world's largest firms: complex and path-dependent, but not much variety, Research Policy, Vol 26, pp141156

Penrose, E. (1959) The theory of the growth of the firm, Wiley: New York 
Porter, M. and Fuller, M. (1986) Coalitions and global strategy, in M. Porter (ed) Competition in Global Industries, Harvard Business School Press,: Boston: pp 315-43

Sachwald, F. (1998) cooperative agreements and the theory of the firm; focusing on barriers to change, Journal of Economic Behaviour and Organisation, Vol 35, pp203-225

Trajtenberg, M. Henderson, R. and Jaffe, A. (1997) University versus corporate patents; a window on the basicness of invention, Economics of Innovation and New Technologies, Vol 5, pp19-50

Veugelers, R. (1997) Internal R\&D expenditures and external technology sourcing, Research Policy, Vol 26, pp 303-315 


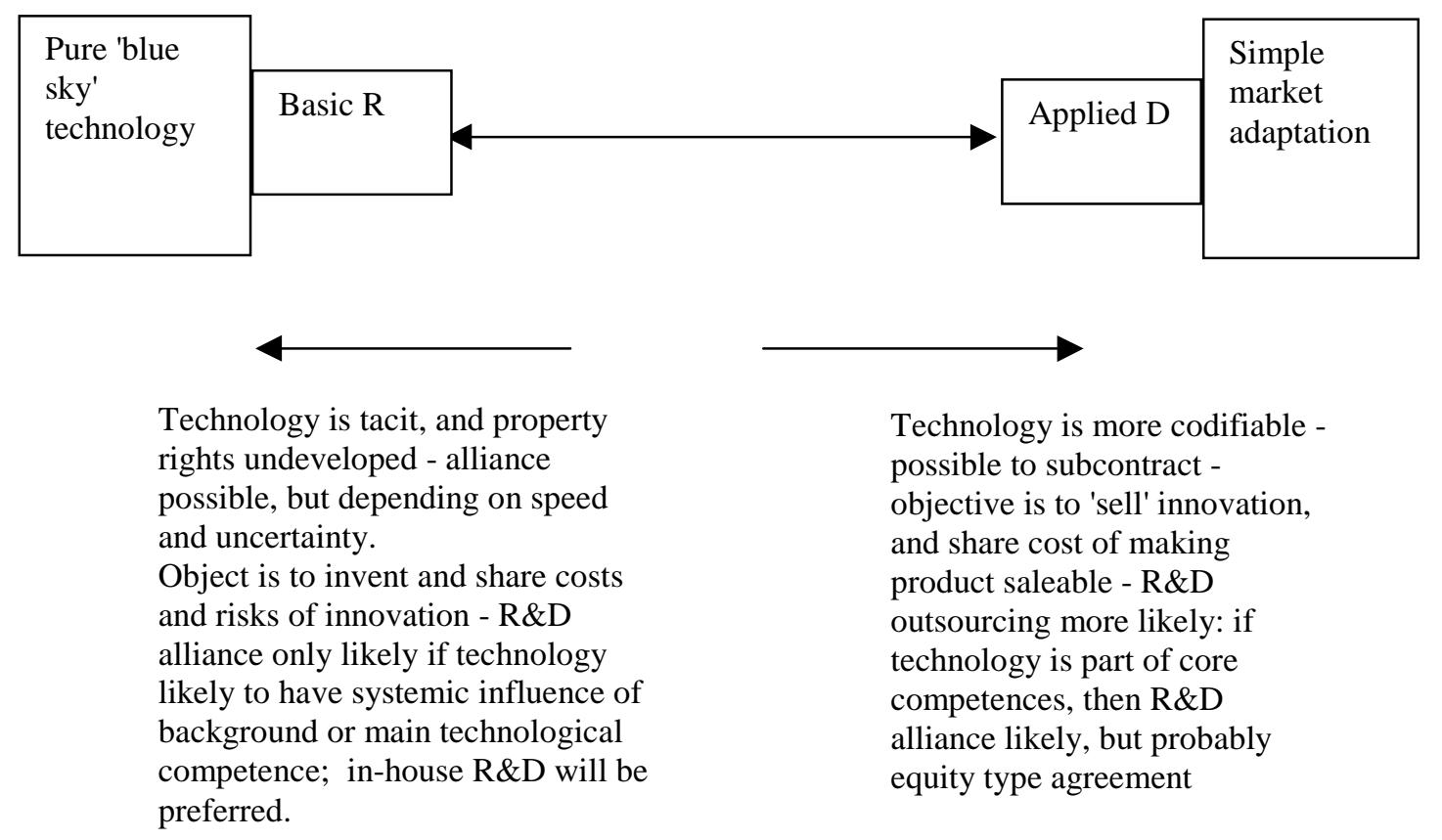

$\underline{\text { Figure } 1 \text { 'Distance-to-market' issues in the innovation process }}$ 


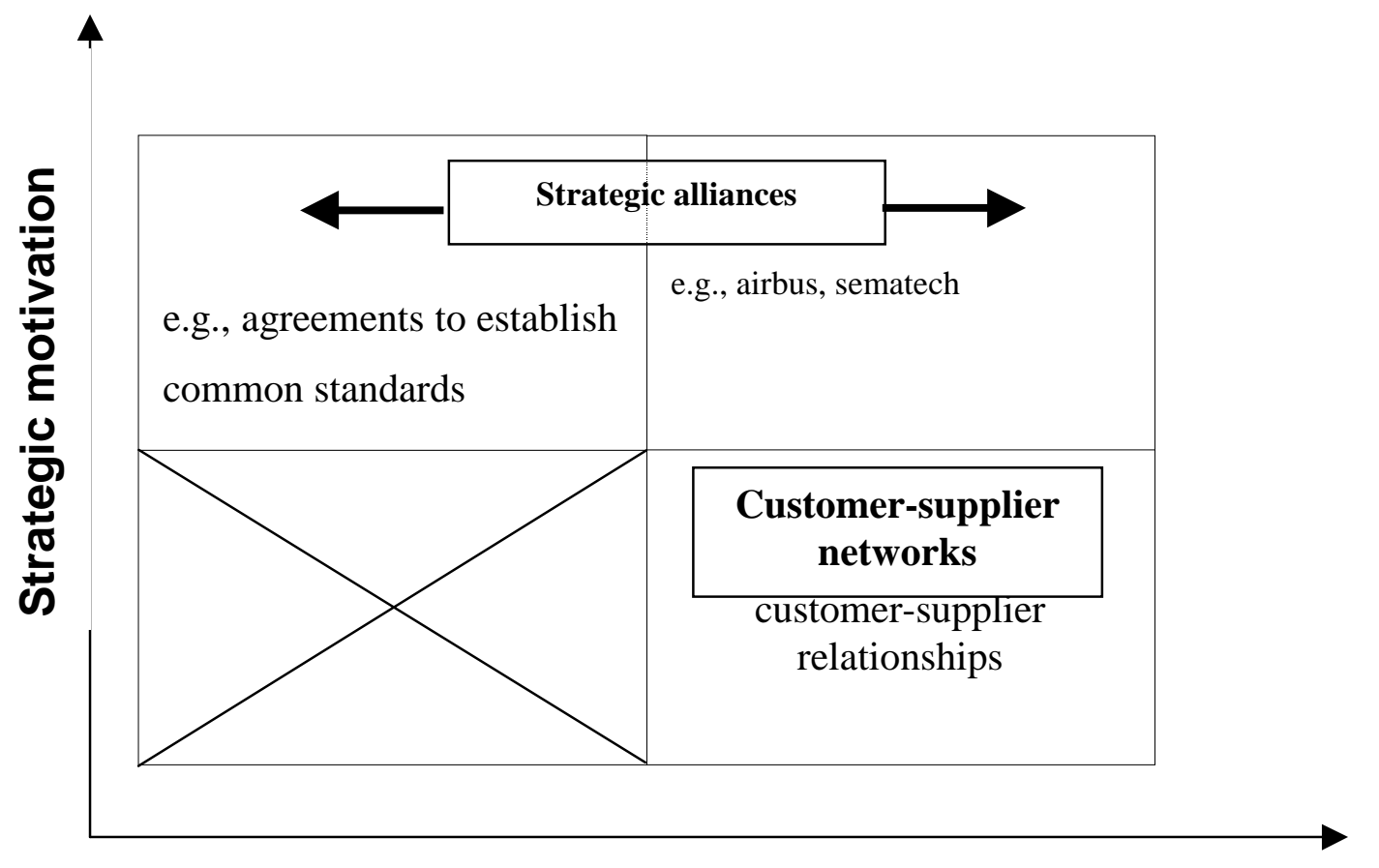

Cost-economising motivation

Figure 2 Explaining the underlying differences between strategic alliances and customer-supplier networks 


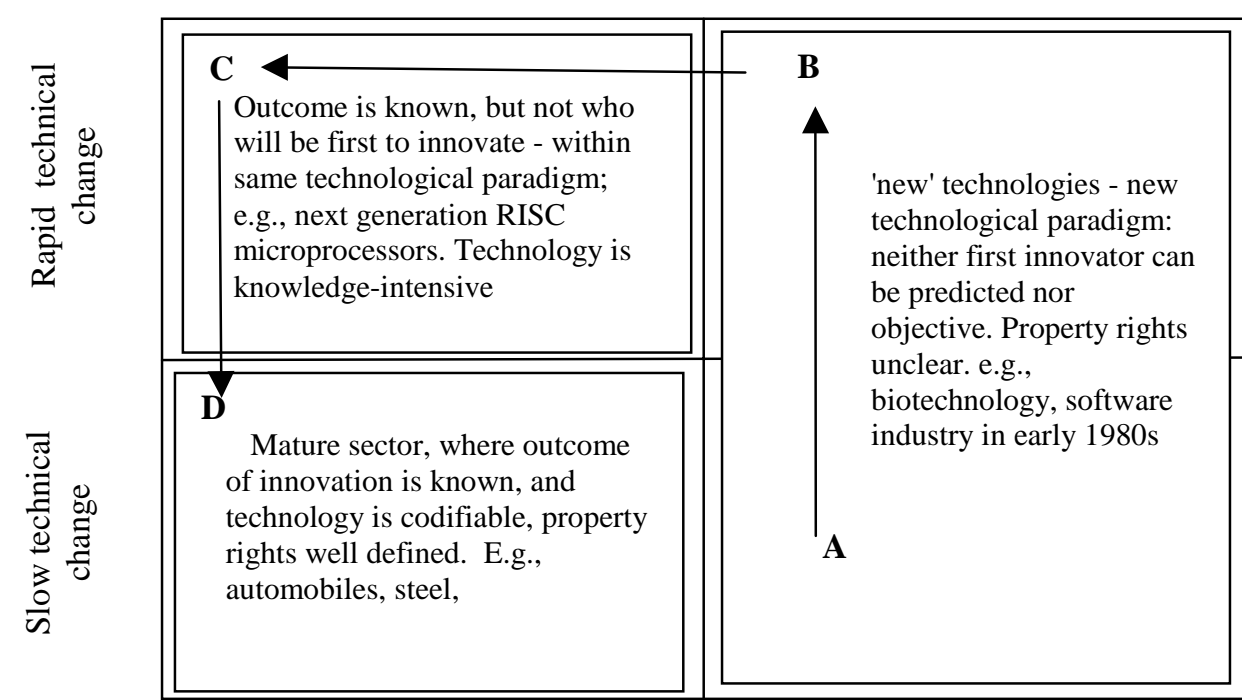

Low uncertainty

High uncertainty

Figure 3: Technological evolution with a given paradigm 


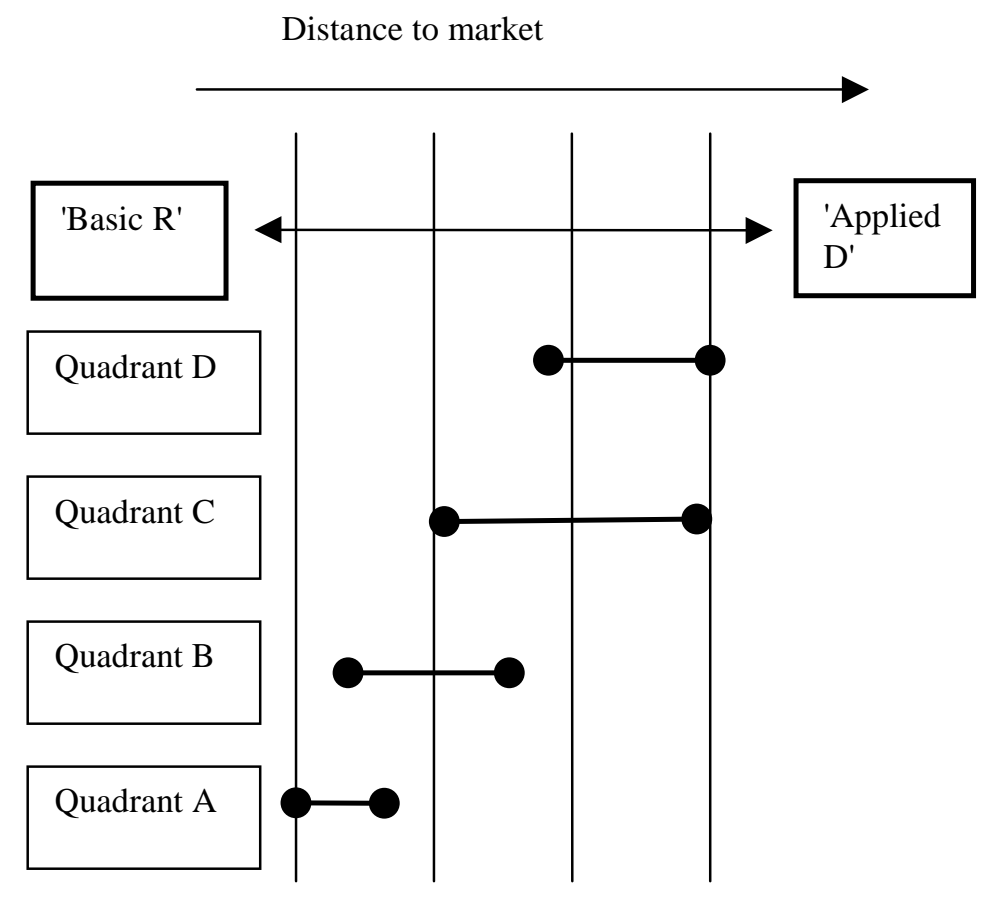

Figure 4 Relating distance-to-market considerations to technological evolution 